\title{
TEACHING AND LEARNING GRAMMAR AND STYLE IN WRITING - A PRACTICAL APPROACH
}

\author{
Larcy C. Abello \\ larcya@yahoo.com \\ English Division, Department of Humanities, College of \\ Arts and Sciences, University of the Philippines at Los \\ Banos
}

\begin{abstract}
This report focuses on the exploration of the three dimensions of grammar-form, meaning, and use-a practical approach to teach and learn grammar and style and effect communication. Using journalistic, literary, and academic/scientific/technical texts, this describes the teachinglearning process involved in language activities, such as text analysis, text conversion, and writing of original texts. This paper explains how the procedure engages students in meaningful tasks that hone their language skills and enhance their writing ability and could inspire them to speak and communicate ideas, applying critical/analytic thinking even outside the classroom thus developing autonomous learners. This demonstrates a practical approach to the teaching of language as communication based on a careful consideration of the nature of language and of the strategic development of writing skills among learners within a supportive social context.
\end{abstract}

Key words: three dimensional grammar framework, communicative environment, transformation vs. transmission

Abstrak: Laporan ini berfokus pada explorasi dari tiga dimensi tata bahasa-nentuk, arti, dan pemakaian-pendekatan yang praktis untuk menagajar dan belajar tata bahasa dan gaya serta efek dari komunikasi. Dengan memakai cara jurnalistik, sastra, adan akademik/ keilmiahan/tekstual teknis, hal ini mendeskripsikan proses belajar-mengajar yang dilibatkan dalam kegiatan pengajaran bahasa, seperti analisis teks, konversi teks, dan penulisan dari teks-teks yang orisinal. Makalah ini menjelaskan bagaimana prosedur ini membuat mahasiswa melakukan kegiatan yang bermanfaat dan membuat mereka lebih trampil pada ketrampilan bahasanya dan memperbaili ketrampilan menulisnya karena dapat mereka terinspirasi untuk 
Abello, L. C., Teaching and Learning Grammar and Style in Writing -

A Practical Approach

berbicara dan mengkomunikasikan ide-idenya, menerapkan pemikiran kritis dan analitisnya meskipun berada di luar kelas, sehingga menciptakan para siswa yang mandiri. Hal ini mendemonstrasikan sifat alami bahasa dan perkembangan yang strategis dari penegembangan ketrampilan menulis siswa dengan konteks social yang mendukung.

Kata kunci: pemikiran tiga dimensi tatabahasa, lingkungan yang komunikatif, transformasi us transmisi

\section{LANGUAGE LEARNING AND TEACHING}

The view of language as a system of rules and learners must internalize them is long gone. Nunan (2009) declares that language is now seen as a system for the expression of meaning and linguists analyze language as a system of meanings, instead of as a system of rules. Grammar of a language, in particular, requires skill development and not a simple knowledge transmission. Instead of viewing it as a set of rules to be followed and memorized, it must be better regarded as a skill to be nurtured, honed, and mastered. Larsen-Freeman (1997; 2001) suggests it is better to think of teaching "grammaring" rather than "grammar", so that students will be motivated to convey meaning accurately in an appropriate manner (emphasis mine). This realization that language could be analyzed, described, and taught as a system of expression has a profound effect on language learning and teaching.

\section{COMMUNICATIVE APPROACH}

Tayao (2010) contends that the language theory which says that language is for use as a means of communication in the real world, requires that for learners to be communicatively competent, they need to develop four competencies: linguistic or command of the elements of the language (sounds, vocabulary, grammar); sociolinguistic, taking into account the context of the situation (who you are addressing, where, when, what the topic is and the purpose of the exchange); discoursal, meaning text structure, coherence, and cohesive flow of ideas in extended texts; and strategic or the means taken to make sense of and in what is uttered. 


\section{THREE DISTINCT TEXT TYPES}

Further, Tayao (2008) suggests the shift in the theory of language from language as a code to language as a means of communication, and then to language as a tool of communication in the real world makes it necessary that all three text types-journalistic, academic/scientific/technical, and literary-be used as these are the authentic materials that language users are likely to encounter in the real world.

\section{THREE DIMENSIONS OF GRAMMAR-FORM, MEANING, USE}

The developments in language teaching and learning affirm the position of Larsen-Freeman (1995) as regards the three dimensions of grammar that is the clear interconnectedness of form, meaning, and use. Larsen-Freeman (2001) sees grammar as a higher-order concept within linguistics with interrelated dimensions. This integrates three aspects of linguistics; syntax (form); semantics (meaning); and pragmatics (use). This greatly shares in common with the model of systemic-functional linguistics developed by Halliday (1985).

\section{PRACTICAL APPROACH TO IMPROVING GRAMMAR AND STYLE IN WRITING}

It is undeniable that the Constructivist View of teaching facilitates learning. As Alonzo (2008) emphasizes in her lecture, there must be an encouragement of self-directed learning and transformation of knowledge rather than teacher-structured and transmission of knowledge. This further brings into focus the idea put forward by Williams (2011) articulating that the teacher today is more of an interpreter, mediator, negotiator, and facilitator of contextualized knowledge.

\section{A. Creating a Communicative Environment}

Emphasis on interaction allows students to converse and prepare them for writing and presentation tasks. This is in consonance with the idea of Bruffee (1984) that for people to think well, they must first learn to talk and reason in their community. A rich social context in the form of discussion and collaboration will cue the cognitive action necessary for both speaking and writing. As Oxford (2001) further elucidates, integration of skills paves the way to achieving authentic communication. Hence, there is a 
Abello, L. C., Teaching and Learning Grammar and Style in Writing -

need for a teacher to provide a suitable context for the target learners. An activity that integrates the skills of listening, speaking, reading and writing will make it possible.

\section{B. Exploring Form, Meaning, and Function in Different Text Types}

In this article I hope to offer a practical tip to tailor activities that will cater to the different learning styles and meet the varied and legitimate needs of students in a particular class, as it is not possible and feasible to just follow a one-activity-fits-all philosophy.

In the following lesson plan, the three dimensions of grammar, namely; form (structure), meaning (semantics) and function (pragmatics) are the focus as the students discuss, collaborate, and perform tasks such as analysis of authentic texts, conversion from one text type into another type, and writing of own/original texts.

\section{PHASE I-... Whole Class}

Step 1: Before Reading

1. Discuss grammatical aspects prominent among texts, specifically the form of language used, the meaning created, and the function achieved.

2. Discuss vocabulary and choice of words used to highlight difference/s among text types.

3. Prepare to answer the following questions:

a. What do you notice about the grammar and vocabulary used?

b. What could be the purpose of communication? Who is/are addressed?

c. Is there a smooth flow of ideas? What cohesive elements are used?

d. How do you make sense of the given information?

Step 2: Reading

Students do reading of the texts and pay close attention to grammatical aspects, vocabulary, and choice of words.

Step 3: After Reading 
1. The teacher facilitates a class discussion about the elements of the reading texts.

2. The students are grouped (dyads/triads) and encouraged to do further analysis, comparison and contrast, etc. They can elaborate their answers on questions like the following:

a. When/Why does a writer choose a particular word and grammar structure instead of another to express a particular meaning and achieve a particular aim?

b. When/why does a writer vary the form of certain linguistic structures?

Step 4: Preparing a Presentation

1. Each group summarizes the salient points raised/ gathered from the discussion.

2. A volunteer from each group presents the summarized result while other groups are allowed to share their views and give further comments/ suggestions.

3. The teacher summarizes the ideas generated from the discussion and prepares students for an assigned task to be accomplished at home.

Step 5: Homework

Each student chooses an authentic text for analysis following the procedure done in whole class mode.

PHASE II----Individual

1. Each student presents his work in class and classmates give their reactions and comments.

2. Each classmate hands in a written peer evaluation.

3. Each student improves/polishes her written work before submitting her final output.

\section{Additional Pointers}

The above mentioned plan holds true for all text types (literary, journalistic, and academic/scientific/technical) and activities (analysis of authentic texts, conversion of text from one type into another type, and writing own/original texts). Each student engages all classmates in a meaningful exchange of ideas prior to finalizing an output. The process 
encourages learners to value discussion, collaboration and negotiation in doing analysis and conversion in preparation for writing an original text. As the student gets accustomed to the task of focusing on form, meaning, and function, he develops confidence in using grammar and vocabulary without worrying too much about syntactic rules. Further, the communicative environment supports and strengthens his resolve to develop speaking, thinking, evaluating, synthesizing and eventually creating and putting his thoughts into clear writing. The procedure creates a community of language learners who are focused on a single goal that is to learn in a meaningful way.

Finally, the teacher is the best person/facilitator to decide whether the students are ready to handle independent work after a whole class activity. If after discussion and interaction and the students still appear unprepared then a small group or pair work can be good options because scaffolding is another strategy that can be utilized to gain productive teaching and learning. What matters most in this approach is for the students to become independent, confident, and self-directed communicators of ideas who can listen, speak, read, write and view information effectively.

\section{Sample Materials}

A rich collection of samples generated from the activity includes analyses of a recipe, contract of employment, and an advertisement for authentic texts; conversion of an Honor Code System of a government agency into a personal essay and a chapter from a novel into a news report; and original texts consisting of an advertorial and a short story, just to mention a few. The samples illustrate the varied and many interests of students signified by their choice of materials. Their freedom to choose which texts to analyze, convert or write for an original output encourages confidence-building and motivates critical thinking and decision-making. These are simple but practical measures to develop autonomous learners which, in this case, fulfill some characteristics that define autonomous learners according to Wenden (1998) and Omaggio (1978) as cited in Farrell (2013), namely; "they take an active role in learning tasks given to them; they are willing to take risks, that is, communicate in L2 without fear of mistakes; they pay attention to form as well as to content, critically examining both accuracy and appropriacy" (p. 8). 


\section{CONCLUSION}

Language teaching and learning can be facilitated through meaningful and practical activities like analysis, conversion, and eventually writing of original texts. With the mediation of a supportive teacherfacilitator, learners can be assisted to differentiate text types based on form, meaning, and function of language, to transform one text type into another, and finally write their own texts applying the knowledge gained from analysis and conversion. All these teaching-learning processes happen within a supportive social context where learners discuss and collaborate to exchange views and share insights thereby producing self-directed learners equipped with knowledge and skills that they can apply even outside the classroom. Three important areas of student performance are enhanced, namely; comprehensibility (how well are they understood?), comprehension (how well do they understand?), and language control (how accurate is their language?). I hope that this approach will be helpful to teachers to make their classes more relevant, practical, and fun.

\section{REFERENCES}

Alonzo, R. ( 2008). Benchmarks. Paper presented at the PALT Conference. December 2008.

Bruffee, K. A. (1984). Collaborative learning and the "conversation of mankind”. In College English 46 (7), 635-652.

Farrell, G. (2013). Autonomous language learning. The English Connection.17 (1).

Larsen-Freeman, D. (ed.) (1995). Grammar dimensions. Boston, MA: Heinle $\&$ Heinle.

Larsen-Freeman, D. (2001). Teaching language: From grammar to grammaring. Boston, MA: Heinle \& Heinle.

Nunan, D. (2009). Second language teaching and learning. Philippine Branch: Cengage Learning Asia Pte. Ltd.

Oxford, R. (2001). Integrated skills in the ESL/EFL classroom. Washington, DC: ERIC Clearing House for Language and Linguistics. ERIC Digest ED 456670. 
Abello, L. C., Teaching and Learning Grammar and Style in Writing -

Tayao, M.L. G. (2008). The whole language approach to reading. A paper presented at the PALT Conference. December 2008.

Tayao, M.L.G. (2010). A new look at the multi-faceted roles of a language teacher with focus on the teacher as a strategy coach. A paper presented at the PALT Conference. December 2010.

Williams, A. (2011). Quoted from a speech delivered at Thai TESOL Conference. January 2011.

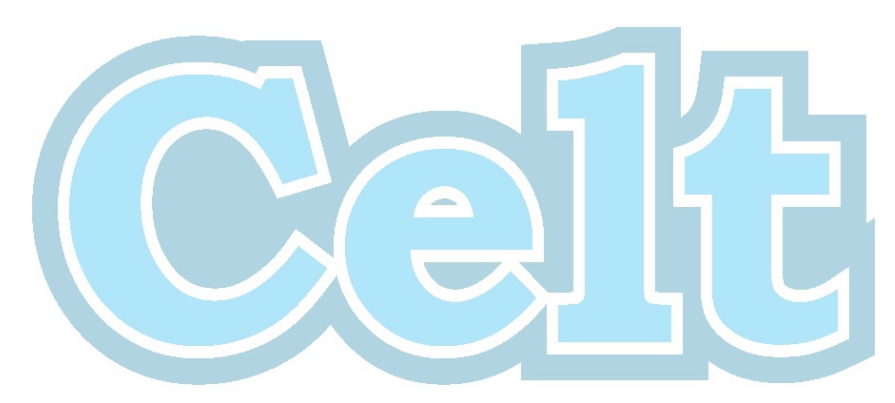

